\title{
PRINSIP EFISIENSI DALAM PERADILAN TINDAK PIDANA PERIKANAN
}

\author{
Sayidin Abdullah \\ Law Firm Sayidin, Sitompul and Partners Jakarta \\ Email : sayidinabdullah@gmail.com
}

\begin{abstract}
This article seeks to examine the principle of efficiency in the execution of fisheries court. Based on the normative approach by using secondary data; can be concluded that the Fisheries Court is the Special Court in the scope of General Court that has an authority to examine, hear and decide criminal offenses of fisheries. Law on Fisheries is one of the cornerstones of a fundamental change in the law enforcement process of fisheries, through Fisheries Court by applying the principle of efficiency. Selection of efficiency principle is based on the simplicity to be understood, because it does not require the technical formulation of economics or figures. The focus of attention is regard to the possibility of emergence an inefficiency of the establishment, implementation and enforcement of legislation, namely the offenses fisheries, which includes investigation, prosecution, and examination against the criminal activities of fisheries in foreign fishing vessels which is doing an illegal fishing in the exclusive economic zone of Indonesia can be resolved by litigation that fulfill the principles of efficiency that is fast, accurate, and inexpensive.
\end{abstract}

Keywords: Efficiency, Fisheries Court and Economic Law

\begin{abstract}
abstrak
Artikel ini berusaha menelaah penerapan prinsip efisiensi dalam pelaksanaan peradilan perikanan. Berdasarkan pendekatan normatif dengan menggunakan data sekunder disimpulkan bahwa pengadilan Perikanan adalah Pengadilan Khusus di lingkungan peradilan umum yang berwenang memeriksa, mengadili, dan memutus tindak pidana di bidang perikanan. Undang-Undang Perikanan merupakan salah satu tonggak perubahan yang mendasar dari suatu proses penegakan hukum di bidang perikanan melalui Pengadilan Perikanan dengan menerapkan prinsip efisiensi. Pemilihan prinsip efisiensi ini berdasarkan pada kemudahannya untuk dipahami, karena tidak memerlukan rumusan-rumusan teknis ilmu ekonomi atau rumus berupa angka-angka. Yang menjadi fokus perhatian adalah berkenaan dengan kemungkinan munculnya ketidakefisienan (inefficiency) dari pembentukan, penerapan maupun penegakan hukum (enforcement) dari peraturan perundang-undangan, yaitu terhadap tindak pidana bidang perikanan, yang
\end{abstract}


mencakup penyidikan, penuntutan, dan pemeriksaan di sidang pengadilan terhadap limpahan perkara pidana perikanan yang diajukan oleh kejaksaan ke pengadilan tentang adanya tindak pidana bidang perikanan kapal ikan asing yang melakukan illegal fishing dengan locus di zona ekonomi eksklusif Indonesia (ZEEI) dapat terselesaikan proses pengadilan memenuhi prinsip efisiensi yaitu cepat, cermat, dan berbiaya ringan.

Kata kunci : Efisiensi, Peradilan Perikanan dan Hukum Ekonomi.

\section{A. Pendahuluan}

Sejak pergantian rezim orde baru kepada rezim orde reformasi sampai saat ini pertanyaan publik dan para ahli hukum tentang arah politik hukum Indonesia di tengah-tengah "himpitan" tekanan ideologi globalisasi menjadi penting dan relevan dengan bagaimana Indonesia mempersiapkan tatanan hukum (sistem hukum) yang memperhatikan keseimbangan antara kepentingan domestik dan kepentingan hubungan internasional di segala bidang kehidupan bangsa dan bagaimana sistem hukum Indonesia memasukan dua kepentingan yang kontroversial, yaitu kepentingan negara di satu sisi dan kepentingan warga negara di sisi lain. UUD 1945 dengan perubahannya merupakan hukum dasar (ground-norm) dan sekaligus merupakan falsafah bangsa Indonesia yang menjadi tonggak tegaknya kedaulatan hukum dan NKRI dalam kehidupan bidang sosial, budaya, ekonomi, politik, dan bidang hukum. ${ }^{1}$

Pembangunan bidang hukum adalah perkembangan perubahan sistem nilai yang dianut bangsa Indonesia mengenai perbuatan yang patut atau tercela, efisien dan efektif, atau bermanfaat atau tidak bermanfaat bagi kehidupan sehari-hari dan masa depan bangsa Indonesia. Ciri perkembangan perubahan sistem nilai dalam suatu sistem hukum adalah ciri utama sekaligus karakteristik khas kemajuan suatu bangsa dalam menyangga kepentingan domestik dan kepentingan hubungan internasional atau salah satu dari keduanya. Pilar penyangga dalam UUD 1945 dan perubahan yang saya pandang penting dan relevan terhadap segala situasi baik kini dan masa mendatang adalah kelima pokok pemikiran (sila-sila) yang tercantum dalam Pancasila dan dalam Pembukaan UUD 1945 dan perubahannya, dan menjiwai seluruh kesatuan batang tubuh tanpa kecuali. Sekalipun UUD 1945 dan perubahannya meberikan celah landasan konstitusional untuk membentuk hukum dalam keadaan darurat hal ikhwal kegentingan yang

\footnotetext{
${ }^{1}$ Romli Atmasasmita,Peran Hakim dalam meningkatkan Profesionalisme Hakim Menuju Peradilan Yang Agung, Makalah Seminar Nasional IKAHI dalam rangka Ulang Tahun IKAHI ke 59 Tanggal 25 April 2012
} 
memaksa, ${ }^{2}$ pembentukannya tetap harus diletakkan dalam kerangka tujuan kepastian hukum, keadilan, dan kemanfaatan terbesar untuk perlindungan HAM setiap warga negara bukan sebaliknya.

Persoalan utama dalam perjalanan hidup bangsa Indonesia adalah bagaimana meletakkan perkembangan kebutuhan dan aspirasi masyarakat ke dalam program legislasi nasional (prolegnas) di tengah-tengah persaingan global saat ini dan di masa yang akan datang. Penetapan prolegnas tersebut, ${ }^{3}$ sejatinya adalah merupakan kebijakan yang cerdas dan mengandung integritas tinggi sebagai bangsa yang dapat menempatkan kepentingan nasional di tengah-tengah hubungan internasional. Kenyataan penetapan prolegnas menunjukkan bahwa pemerintah belum memiliki keberanian dan komitmen kuat untuk memegang teguh amanat UUD 1945 dan perubahannya termasuk ketentuan-ketentuan yang mengatur kehidupan bangsa yang bersifat srategis terutama tampak dalam peraturan perundangundangan dalam bidang ekonomi, sosial dan politik, serta sumber daya alam.

Hukum haruslah dapat merespon segala seluk-beluk kehidupan sosial yang melingkupinya agar tidak tertinggal dari perkembangan masyarakat. Oleh karena itu, peranan hukum menjadi sangat penting dalam menghadapi permasalahan sosial yang akan muncul nantinya. Dalam konteks demikian, hukum tidak hanya dipahami secara yuridis normatif saja, tetapi juga harus dipahami secara deskriptif melalui pendekatan ilmu-ilmu sosial. Studi hukum non-yuridis normatif telah menunjukkan bahwa hukum bukan lagi sebagai lembaga yang otonom melainkan sebagai suatu proses sosial dengan memanfaatkan hasil dari karya para ahli ilmu sosial dalam menghadapi masalahnya. Tak dapat dipungkiri, bahwa perkembangan masyarakat semakin maju dan kompleks. Oleh karena itu, diperlukan aturan hukum yang sejalan dengan hal tersebut. Hukum memegang peranan yang sangat penting sebagai kerangka kehidupan sosial masyarakat modern.

Law and economics awalnya merupakan gagasan dari ekonom (nonhukum) yang melihat adanya potensi memanfaatkan instrumen hukum demi tercapainya hasil optimal dalam menerapkan kebijakan publik khususnya dalam bidang ekonomi. Ahli hukum menyambut baik gagasan tersebut dalam upaya mengatasi permasalahan yang terjadi di masyarakat. Tidak dapat dipungkiri, bahwa unsur ekonomi dalam pembuatan kebijakan, baik pada tingkat pembentukan, implementasi maupun law enforcement peraturan perundang-undangan telah sangat berpengaruh di Indonesia. Secara resmi Garis-Garis Besar Haluan Negara (GBHN) menetapkan salah satu arah Kebijakan Program Pembangunan Nasional Bidang Hukum, yakni mengembangkan peraturan perundang-undangan yang mendukung kegiatan

\footnotetext{
${ }^{2}$ Ibid.

${ }^{3}$ Pasal 22 UUD 1945.
} 
perekonomian dalam menghadapi era perdagangan bebas. Tentunya arah kebijakan tersebut merupakan satu indikator kuatnya pengaruh atau tujuan ekonomi dalam perkembangan hukum di Indonesia.

Secara konsepsional, inti dan arti penegakan hukum terletak pada kegiatan menyelaraskan hubungan nilai-nilai yang terjabarkan di dalam kaidah-kaidah yang tetap dan melaksanakan sikap tindak sebagai rangkaian penjabaran nilai tahap akhir untuk menciptakan, memelihara, dan tentu saja dalam proses penegakan hukum ini diharapkan hasil yang optimal, sehingga aturan-aturan hukum pidana berfungsi secara efektif untuk mencegah seseorang melakukan perbuatan-perbuatan yang dilarang, dan kalau ternyata aturan-aturan itu dilanggar, aparat penegak hukum dapat menjalankan fungsinya secara efektif pula. Upaya untuk mewujudkan penegakan hukum pidana yang optimal ini meliputi berbagai macam cara dan pendekatan. Setiap cara dan pendekatan yang digunakan akan berimplikasi pada hasil yang akan dicapai. Salah satu pendekatan yang dapat digunakan untuk mewujudkan penegakan hukum pidana yang optimal adalah pendekatan (analisis) ekonomi. Bagaimana konsep yang ditawarkan oleh pendekatan ekonomi untuk mewujudkan penegakan hukum pidana yang optimal, tulisan ini secara khusus mengkajinya. Dua hal yang penting dan perlu dikemukakan untuk mengetahui penegakan hukum pidana yang optimal dalam perspektif analisis ekonomi ini, yaitu prinsip-prinsip dasar analisis ekonomi atas hukum pidana; dan analisis ekonomi terhadap penegakan hukum pidana yang optimal.

Hal ini dilakukan dengan harapan penerapan hukum tersebut memberikan manfaat kepada negara. Hal ini selaras dengan faham utilitarianisme (Jeremi Bentham) yang berpendapat tingkah laku yang baik adalah yang menghasilkan akibat-akibat baik sebanyak mungkin dibandingkan dengan akibat-akibat buruknya. Setiap tindakan manusia harus selalu dipikirkan, apa akibat dari tindakannya tersebut bagi dirinya maupun orang lain dan masyarakat. Utilitarianisme memunyai tanggung jawab kepada orang yang melakukan suatu tindakan, apakah tindakan tersebut baik atau buruk. Menurut suatu perumusan terkenal, dalam rangka pemikiran utilitarianisme (utilitarianism) kriteria untuk menentukan baik buruknya suatu perbuatan adalah the greatest happiness of the greatest number, kebahagiaan terbesar dari jumlah orang terbesar. Utilitarisme disebut lagi suatu teori teleologis, sebab menurut teori ini kualitas etis suatu perbuatan diperoleh dengan dicapainya tujuan perbuatan.

Prinsip ini menurut Bentham harus mendasari kehidupan politik dan perundangan Pembahasan Hukum merupakan aturan tentang pola tingkah laku orang dalam masyarakat. Pola tingkah laku tersebut harus diatur sedemikian rupa demi untuk menciptakan ketenteraman hidup bersama. Dalam ranah empiris dapat dipahami masing-masing orang memiliki 
kebutuhan yang berbeda-beda, yang sudah dapat dipastikan dalam upaya memenuhi kebutuhan tersebut akan menempuh cara yang berlainan juga. Atau dapat dikatakan bahwa hukum atau ilmu hukum adalah suatu sistem aturan atau adat yang secara resmi dianggap mengikat dan dikukuhkan oleh penguasa, pemerintah atau otoritas melalui lembaga, atau institusi hukum. Ekonomi adalah ilmu yang mempelajari perilaku manusia dalam memilih dan menciptakan kemakmuran. Inti masalah ekonomi adalah adanya ketidakseimbangan antara kebutuhan manusia yang tidak terbatas dengan alat pemuas kebutuhan yang jumlahnya terbatas. Permasalahan itu kemudian menyebabkan timbulnya kelangkaan. Hukum ekonomi adalah suatu hubungan sebab akibat atau pertalian peristiwa ekonomi yang saling berhubungan satu dengan yang lain dalam kehidupan ekonomi sehari-hari dalam masyarakat. Ilmu Ekonomi memprediksi efek kebijakan terhadap efisiensi.

Efisiensi selalu berhubungan dengan pembuatan kebijakan, karena akan selalu lebih baik mencapai semua kebijakan-kebijakan yang ada dengan biaya yang rendah daripada dengan biaya yang tinggi. Selain efisiensi, ilmu ekonomi yang juga memprediksi efek dari kebijakan-kebijakan dalam nilai penting lainnya adalah distribusi. Di antara penerapan ilmu ekonomi itu terhadap kebijakan publik adalah penggunaannya untuk memprediksi nilai daya guna dari aturan serta cost yang harus dikeluarkan. Menurut M. Manulang, ilmu ekonomi adalah suatu ilmu yang mempelajari masyarakat dalam usaha hanya untuk mencapai kemakmuran. Hukum ekonomi lahir disebabkan oleh semakin pesatnya pertumbuhan dan perkembangan perekonomian. Hukum berfungsi untuk mengatur dan membatasi kegiatan ekonomi dengan harapan pembangunan ekonomi tidak mengabaikan hakhak dan kepentingan masyarakat.

Penegakan hukum mencakup pengertian mengenai institusi penegak hukum dan aparat (orangnya) penegak hukum. Dalam arti sempit, aparatur penegak hukum yang terlibat tegaknya hukum itu, dimulai dari saksi, polisi, penasehat hukum, jaksa, hakim, dan petugas-petugas sipir pemasyarakatan. Setiap aparat dan aparatur terkait mencakup pula pihak-pihak yang bersangkutan dengan tugas atau perannya, yaitu terkait dengan kegiatan pelaporan atau pengaduan, penyelidikan, penyidikan, penuntutan, pembuktian, penjatuhan vonis dan pemberian sanksi, serta upaya pemasyarakatan kembali (resosialisasi) terpidana. Upaya penegakan hukum secara sistematik haruslah memperhatikan ketiga aspek itu secara terpadu, sehingga proses penegakan hukum dan keadilan itu sendiri secara internal dapat diwujudkan secara nyata, namun selain ketiga faktor di atas, keluhan berkenaan dengan kinerja penegakan hukum di negara selama ini, sebenarnya juga memerlukan analisis yang lebih menyeluruh lagi. 
Upaya penegakan hukum hanya satu elemen saja dari keseluruhan persoalan sebagai negara hukum yang mencita-citakan upaya menegakkan dan mewujudkan keadilan sosial bagi seluruh rakyat Indonesia. Hukum tidak mungkin akan tegak, jika hukum itu sendiri atau belum mencerminkan perasaan atau nilai-nilai keadilan yang hidup dalam masyarakatnya. Hukum tidak mungkin menjamin keadilan jika materinya sebagian besar merupakan warisan masa lalu yang tidak sesuai lagi dengan tuntutan zaman. Artinya, persoalan yang dihadapi bukan saja berkenaan dengan upaya penegakan hukum tetapi juga pembaharuan hukum atau pembuatan hukum baru. Dalam konteks penegakan hukum akan dapat efektif apabila didukung oleh sistem hukum yang baik. Sistem hukum yang baik apabila dapat mengakomodir kesempurnaan dari substantie, structure, dan culture dari hukum itu sendiri. Sistem hukum (legal system) adalah satu kesatuan hukum yang tersusun dari tiga unsur, yaitu: 1) Struktur; 2) Substansi; dan 3) Kultur Hukum.

Berdasarkan pendapat tersebut, jika kita berbicara tentang sistem hukum, maka ketiga unsur tersebut secara bersama-sama atau secara sendirisendiri, tidak mungkin dikesampingkan. Struktur adalah keseluruhan institusi penegakan hukum, beserta aparatnya. Jadi mencakupi: 1) kepolisian dengan para polisinya; kejaksaan dengan para jaksanya; 2) kantor-kantor pengacara dengan para pengacaranya; dan 3) pengadilan dengan para hakimnya. Substansi adalah keseluruhan asas hukum, norma hokum, dan aturan hukum, baik yang tertulis maupun yang tidak tertulis, termasuk putusan pengadilan. Kultur hukum adalah kebiasaan-kebiasaan, opini-opini, cara berpikir, dan cara bertindak, baik dari para penegak hukum maupun dari warga masyarakat. Oleh karena itu, untuk menuju terciptanya supremasi hukum tentunya memerlukan suatu kerja keras dari seluruh elemen yang ada di negara ini.

Upaya untuk menciptakan supremasi hukum bukan hanya hak lembaga-lembaga negara Indonesia dengan pembagian kekuasaannya yang bercirikan prinsip check dan balances dalam pelaksanaan pemerintahannya, tetapi juga merupakan hak dari setiap warga negara untuk berpartisipasi dalam usaha terciptanya supremasi hukum di negara kita. Pentingnya budaya hukum untuk mendukung adanya sistem hukum, sebagaimana Friedman mengatakan, bahwa substansi dan aparatur saja tidak cukup untuk berjalannya sistem hukum. Di mana Lawrence M Friedman menekankan kepada pentingnya budaya hukum (legal culture).

Sesuai dengan teori ekonomi klasik yang menyatakan bahwa "dengan biaya yang sekecil-kecilnya diharapkan keuntungan yang sebesar-besarnya". Dapat dianalogikan dengan membuat aturan yang sederhana (dalam segala aspek) diharapkan dapat memberikan daya fungsi yang tinggi bagi masyarakat, yakni dapat mengakomodasi seluruh kepentingan yang ada dalam masyarakat. Hal ini diharapkan demi untuk penegakan hukum yang 
baik serta cost yang ringan yang dibebankan terhadap negara. Suatu masyarakat yang sehat cenderung memilih atau menciptakan hukum-hukum yang dapat mempromosikan efisiensi ekonomi dalam setiap produk hukumnya. Untuk mengukur apakah hukum yang dipilih atau diciptakan turut mempromosikan efisiensi ekonomi, maka diperlukan pendekatan terhadap hukum yang tidak semata-mata hukum pada tataran ilmu hukum semata.

Pembangunan hukum nasional di bidang hukum pidana, dilandasi motivasi dan tujuan agar masyarakat menghayati hak dan kewajibanya, meningkatkan pembinan sikap para pelaksana penegak hukum sesuai dengan fungsi dan wewenang masing-masing ke arah tegaknya hukum, keadilan, dan perlindungan terhadap harkat dan martabat manusia, ketertiban serta kepastian hukum demi terselenggaranya negara hukum sesuai dengan Pancasila dan Undang-Undang Dasar 1945. Tindak pidana perikanan yang dilakukan oleh nelayan asing maupun lokal tampaknya merupakan suatu ancaman yang cukup serius dalam penegakan hukum. Secara faktual tindak pidana tersebut ada kecenderungan untuk mengalami peningkatan dari tahun ke tahun, dan terjadi hampir di seluruh pelosok Indonesia. Peningkatan tindak pidana tersebut mengisyaratkan bahwa penanggulangannya harus dilakukan secara sistematik.

Penegakan hukum yang berintegritas harus dapat memulihkan defisit kewibawaan penegakan hukum tindak pidana perikanan. Ruang gerak pelaku tindak pidana perikanan akan semakin sempit jika penegakan hukumnya terintegrasi dengan pemangku kepentingan (stakeholder) tegaknya keadilan sosial ekonomi rakyat, khususnya nelayan Indonesia yang menderita sosial ekonomi akibat pencurian ikan (illegal fishing). Kewibawaan hukum harus ditingkatkan untuk dapat mengembalikan arah pendulum kedaulatan hukum kepada rakyat dan nelayan tradisional yang menjadi korban tindak pidana perikanan karena illegal fishing yang dilakukan warga negara asing berdampak serius secara sosial ekonomi, ekologi, dan kewibawaan negara. Ketegasan untuk menenggelamkan kapal ilegal, merupakan bagian dari upaya pemberian sanksi berdimensi efek jera bagi kapal perikanan ilegal berbendera asing sesuai Pasal 69 Ayat (4) UU Perikanan. Tindakan penenggelaman kapal berbendera asing secara yuridis harus berdasarkan bukti permulaan yang cukup adanya tindak pidana, tak memiliki Surat Izin Penangkapan Ikan (SIPI) dan Surat Izin Kapal Pengangkut Ikan (SIKPI), serta nyata-nyata menangkap dan/atau mengangkut ikan ketika memasuki wilayah pengelolaan Indonesia.

Penanganan terhadap tindak pidana perikanan, sebagai suatu bagian dari sistem penegakan hukum, hanya dapat dilakukan secara baik jika ketiga komponen di atas saling mendukung pada hasil penegakan hukum itu sendiri. Demikian juga kontradiksi antara unsur-unsur dalam satu sub sistem. 
Kekeliruan konseptualisasi tentang konsep klasifikasi laut, akan berpengaruh terhadap perumusan otoritas institusional. Kerancuan alokasi kewenangan terhadap beberapa institusi dalam menegakan hukum akan berpengaruh terhadap efektifitas penegakan hukum itu sendiri. Demikian juga jika terjadi pertentangan antar beberapa aturan hukum yang secara substansial mengatur kewenangan institusional dalam bidang penegakan hukum. Ketidakjelasan kewenangan, sebagai akibat dari ketidakjelasan pengaturan terhadap penegak hukum, terutama pelaksanan Undang-Undang Nomor 45 Tahun 2009 tentang Perikanan.

Berdasarkan uraian tersebut pertanyaan akademik yang diajukan, pertama, bagaimana sistem hukum mencapai tujuan efisiensi bagi kepentingan masyarakat dalam pembentukan dan pelaksanaan peradilan perikanan, dan kedua apakah yg dimaksud efisiensi dalam sistem hukum?

\section{B. Pembahasan \\ 1. Sistem Hukum Mencapai Tujuan Efisiensi Bagi Kepentingan Masyarakat}

Sistem merupakan satu kesatuan yang utuh yang terdiri atas berbagai bagian atau sub sistem. Sub-sistem ini saling berkaitan yang tidak boleh bertentangan, dan apabila memang terjadi pertentangan, maka selalu ada jalan untuk menyelesaikannya. Begitu juga dengan sistem hukum haruslah tersusun dari sejumlah bagian-bagian yang dinamakan sub sistem hukum secara bersama-sama mewujudkan kesatuan yang utuh. Sistem hukum bukan sekedar kumpulan peraturan hukum, tetapi setiap peraturan itu saling berkaitan satu dengan yang lainnya, serta tidak boleh terjadi konflik atau kontradiksi di antara sub-sistem yang ada di dalamnya. Lili Rasyidi, dan I.B. Wyasa Putra, menyatakan bahwa sistem hukum merupakan suatu kesatuan sistem yang tersusun atas integritas sebagai komponen sistem hukum, yang masing-masing memiliki fungsi tersendiri dan terikat dalam suatu kesatuan hubungan yang saling terkait, bergantung, mempengaruhi, bergerak dalam kesatuan proses, yakni proses sistem hukum untuk mewujudkan tujuan hukum. Oleh karena itu, dapat dipahami bahwasanya sistem hukum merupakan keseluruhan aspek dan elemen yang tersusun sebagai satu kesatuan terpadu tentang hukum.

Tingginya ketidakpastian dalam melakukan usaha di Indonesia disebabkan karena keadaan penegakan hukum dan sistem peradilan di Indonesia yang sangat buruk. Banyak putusan pengadilan yang tidak menghormati kesepakatan yang telah dibuat oleh pelaku bisnis, misalnya putusan pengadilan yang mengesampingkan pilihan hukum dan pilihan arbitrase para pihak. Ketidakpastian hukum juga disebabkan karena seringnya pengadilan menolak untuk mengeksekusi perjanjian-perjanjian kredit yang telah disepakati para pihak. Keadaan ini mengakibatkan 
ketidakefisienan dan ketidakpastian dalam melakukan kegiatan usaha karena tidak ada cara efektif pelaku usaha melaksanakan kontrak bisnis mereka, untuk menagih hutang, untuk mengeksekusi agunan, dan untuk menggugat pailit. $^{4}$

Pendapat Charles Himawan ini membenarkan teori peranan penting hukum dalam pembangunan ekonomi yang sudah disuarakan oleh para pakar Law and Economics (Hukum dan Ekonomi), seperti Max Weber, David D. Friedman, dan Richard Posner. Max Weber, sosiolog Jerman, dalam bukunya yang terkenal Die Protestantische Ethikunder 'Geist' des Kapitalismus (Etika Protestan dan Spirit Kapitalisme) menegaskan bahwa hukum yang rasional menjadi dasar dari pembangunan ekonomi karena dengan hukum yang rasional, pelaku usaha dapat memprediksi dan mengkalkulasikan aktivitas ekonominya sehingga memberikan kepastian berusaha (certainty) yang sangat dibutuhkan oleh setiap pelaku usaha. ${ }^{5}$

Sedangkan Richard Posner dan David Friedman percaya bahwa sistem hukum yang baik justru dapat meningkatkan efisiensi dalam perekonomian sehingga mengurangi biaya ekonomi (economic cost) dan biaya sosial (social cost) yang harus ditanggung pelaku usaha. ${ }^{6}$

Desentralisasi atau otonomi daerah memberikan peluang bagi pemerintah daerah ditingkat provinsi, kabupaten, dan kotamadya untuk menerbitkan peraturan-peraturan daerah yang saling tumpang tindih. ${ }^{7}$ Sebagai akibatnya, muncul ribuan peraturan daerah yang sebagian besar mengatur penarikan pajak dan berbagai macam pungutan untuk meningkatkan pendapatan asli daerah (PAD). ${ }^{8}$ Tendensi ini semakin diperparah dengan adanya persepsi di kalangan pemerintah daerah bahwa kesuksesan suatu pemerintah daerah ditentukan oleh besarnya PAD yang bisa mereka peroleh. ${ }^{9}$ Tanpa adanya pembagian kewenangan yang jelas antara pemerintah tingkat provinsi, tingkat kabupaten, dan tingkat kotamadya, masing-masing pemerintah tersebut menerapkan pajak dan pungutan berulang kali kepada para pengusaha dan investor yang beroperasi

${ }^{4}$ Charles Himawan, Hukum Macet Penyebab Utama Kredit Macet, Kompas, 5 dan 6 Agustus 1993, hlm.4

5 Max Weber,Die Protestantische Ethik und der 'Geist' des Kapitalismus (1905) diterjemahkan oleh Talcott Parsons, The Protestant Ethic and the Spirit of Capitalism (New York: Dover Publications, 2003) David M. Trubek, Max Weber on Law and the Rise of Capitalism, Wisconsin Law Review 3 (1972): hlm. 720-753.

${ }^{6}$ Richard A. Posner, Economic, Analysis of Law, $7^{\text {th }}$ ed. (Wolters Kluwer Law \& Business, 2007) David D. Friedman, Law and Economics [artikel online] (2002, diakses 27 Maret 2010) dari http://www.econlib.org/library/Enc1/LawandEconomics.html

7 "Hubungan Pusat-Daerah: Kewenangan Tumpang Tindih Menjadi Tidak Produktif" KOMPAS, 22 Mei 2009, hlm. 41.

8 "Ribuan Perda Baru yang Bikin Pusing" KOMPAS, 14 August 2003

${ }^{9}$ Syaikhu Usman, et. al., Regional Autonomy and the Business Climate: Three Kabupaten Case Studies from North Sumatra (Indonesia: SMERU, 2001) 
di wilayahnya. Dengan penerapan otonomi daerah, pemerintah daerah saat ini juga memiliki kewenangan untuk memberikan izin investasi di wilayahnya (kecuali untuk investasi di bidang minyak dan gas bumi). Akan tetapi, tanpa adanya prosedur perizinan investasi yang standar di daerahdaerah, proses melakukan investasi menjadi rumit, makan waktu, dan berbiaya tinggi. ${ }^{10}$

Semua peraturan daerah ini akhirnya menciptakan perekonomian yang tidak efisien, berbiaya tinggi, dan penuh ketidakpastian, yang membuat Indonesia menjadi tempat yang tidak menarik lagi untuk berinvestasi dan berbisnis. ${ }^{11}$

Di samping disebabkan oleh desentralisasi, masalah ketidakpastian hukum dalam era Pemerintahan Reformasi juga disebabkan oleh terlalu banyaknya peraturan yang dibuat oleh Pemerintah, yang saling bertentangan satu sama lainnya. Peraturan-peraturan ini pada umumnya diterbitkan oleh kementerian-kementerian atau lembaga-lembaga negara yang tidak melakukan koordinasi di antara mereka. Terlalu banyaknya peraturan memaksa pelaku usaha untuk memberikan biaya tidak resmi dan suap guna mempercepat proses perizinan, clearance, dan layanan pemerintah lainnya. ${ }^{12}$

Hal ini mengakibatkan ekonomi biaya tinggi dan korupsi masih umum terjadi di Indonesia seperti di zaman Pemerintahan Orde Baru. Kebiasaan pemerintah Reformasi untuk menerbitkan peraturan-peraturan yang berlaku mundur (retroactive) juga memunculkan ketidakpastian hukum bagi investor asing maupun domestik. Peraturan-peraturan yang retroactive tersebut telah memunculkan konflik hukum antara investor dan Pemerintah. Salah satu contohnya adalah peraturan retroactive di bidang perpajakan. Menteri Keuangan menerapkan Peraturan Pemerintah yang baru, yaitu Peraturan Pemerintah (PP) nomor 144 tahun 2000 tentang Jenis Barang dan Jasa yang Tidak Dikenakan Pajak Pertambahan Nilai, kepada perusahaan produsen batubara yang berada di bawah Perjanjian Karya Pengusahaan Pertambangan Batubara (PKP2B) generasi I. Berdasar PKP2B generasi I, batubara dikategorikan sebagai barang kena pajak dan produsen batubara memperoleh restitusi pajak pertambahan nilai (PPN) setiap tahunnya. Berdasar sistem perpajakan tetap yang disepakati pemerintah dalam PKP2B generasi I, produsen batubara dikenai tarif pajak perseroan jauh lebih tinggi, yakni $45 \%$ dibandingkan tarif pajak tertinggi sesuai aturan perpajakan yang hanya $30 \%$. Produsen batubara yang berada di bawah PKP2B generasi I tidak dapat menerima pemberlakuan PP nomor 144 tahun 2000 yang tidak lagi

\footnotetext{
${ }^{10}$ OECD, Economic Assessment of Indonesia 2008 (OECD, 2008) Asian Development Bank, Op.Cit.

${ }^{11}$ Fenomena ini membenarkan teori Law and Economics yang diajarkan oleh antara lain Max Weber dan Richard Posner tentang kedudukan hukum dalam pembangunan ekonomi.

${ }^{12}$ Asian Development Bank, Op.Cit., hlm. 36.
} 
mengategorikan batubara sebagai barang kena pajak sehingga mereka tidak dapat lagi memperoleh restitusi PPN. Mereka menganggap bahwa Pemerintah telah melanggar sistem perpajakan tetap yang disepakati pemerintah dalam PKP2B generasi I. Sebagai tindakan balasan atas pelanggaran Pemerintah terhadap kesepakatan PKP2B generasi I, empat belas perusahaan produsen batubara tidak lagi bersedia membayar royalti dana hasil produksi batubara (DHPB) mereka sejak 2001 ke Pemerintah. Pada awal bulan Agustus 2008, Menteri Keuangan mengajukan permohonan cekal kepada Dirjen Imigrasi atas direktur dan komisaris empat belas perusahaan batubara yang menunggak royalti DHPB. ${ }^{13}$

Kasus penahanan royalti yang berlanjut pada pencekalan ini menuai kontroversi karena pencekalan tersebut juga melibatkan beberapa pengusaha berkewarganegaraan asing. Hal ini memaksa Presiden Yudhoyono turun tangan menengahi sengketa antara perusahaan batubara dan Departemen Keuangan. Pada tanggal 13 Agustus 2008, Presiden Yudhoyono memerintahkan Menteri Keuangan dan Menteri Energi dan Sumber Daya Mineral untuk mengakhiri ketidakpastian hukum. ${ }^{14}$ Akhirnya pada bulan Oktober 2008, Dirjen Imigrasi mencabut pencekalan atas direktur dan komisaris perusahaan batubara yang menunggak royalti, setelah perusahaan batubara mereka bersedia untuk membayar royalti batubara yang mereka tahan sejak 2001. Demikian pula, Departemen Keuangan beserta Departemen Energi dan Sumber Daya Mineral berjanji untuk membayarkan restitusi pajak PPN yang belum diterima oleh keempat belas perusahaan batubara tersebut. ${ }^{15}$

Contoh lain dari peraturan retroactive yang menimbulkan ketidakpastian hukum bagi investor adalah perubahan peraturan di bidang Kontrak Karya dan Perjanjian Karya bagi perusahaan pertambangan. Undang-Undang Pertambangan yang baru, Undang-Undang Nomor 4 Tahun 2009 tentang Pertambangan Mineral dan Batubara (Pertambangan Minerba), yang menggantikan Undang-Undang Nomor 11 Tahun 1967 tentang Ketentuan-Ketentuan Pokok Pertambangan, memberikan posisi yang lebih kuat kepada Pemerintah Indonesia di hadapan investor produsen batubara.

\footnotetext{
${ }^{13}$ Dirjen Imigrasi Cekal 14 Pemimpin Perusahaan Tambang Batubara", [koran online] (5 Agustus 2008, diakses 28 Maret 2010) dari http://www.kontan.co.id/index.php/ nasional/news/626/Dirjen-Imigrasi-CekalPemimpin-Perusahaan-Tambang-Batubara.

14 Batubara Membara, [koran online] (11 Agustus 2008, diakses 28 Maret 2008) dari http://cetak.kompas.com/read/xml/2008/08/11/00570150/batu.bara.membara.Royalti Batubara, Presiden: Hindarkan Ketidakpastian Hukum", [koran online] (14 Agustus 2008, diakses 14 Agustus 2008) dari http://www.kompas.com/read/xml /2008/08/ 14/00020617/presiden.hindarkan.ketidakpastian.hukum

${ }^{15}$ Pencekalan Pengusaha Batubara Dicabut, [koran online] (10 Oktober 2008, diakses 10 Oktober 2008) dari http://www.republika.co.id/koran/16/6793/Pencekalan_Pengusaha _Batu_Bara_Dicabut.
} 
Berdasarkan undang-undang Pertambangan yang lama, Pemerintah Indonesia memiliki kedudukan yang sejajar dengan investor produsen batubara di dalam Kontrak Karya atau Perjanjian Karya. Karena posisi yang sejajar sebagai pihak dalam Kontrak Karya atau Perjanjian Karya, Pemerintah Indonesia tidak dapat melakukan perubahan apapun terhadap Kontrak Karya atau Perjanjian Karya tanpa persetujuan pihak produsen batubara. Di dalam Undang-Undang Pertambangan Minerba yang baru ini, Pemerintah Indonesia tidak lagi ditempatkan dalam kedudukan sejajar dengan investor produsen batubara, akan tetapi ditempatkan sebagai pemberi izin bagi investor untuk melakukan pengusahaan pertambangan. Dengan posisi sebagai pemberi izin, Pemerintah Indonesia akan memiliki kewenangan yang lebih kuat untuk mengatur produsen pertambangan. Oleh karena itu, Pasal 169b Undang-Undang Nomor 4 Tahun 2009 tentang Pertambangan Mineral dan Batubara menyaratkan agar setahun setelah diundangkannya Undang-Undang ini seluruh Kontrak Karya dan Perjanjian Karya yang ada digantikan dengan Izin Usaha Pertambangan (IUP). Peraturan yang berlaku mundur (retroactive) ini menimbulkan ketidakpastian hukum terhadap status Kontrak Karya dan Perjanjian Karya yang sedang berjalan dan memaksa para pihak untuk mengubah kontrak mereka sebelum berakhirnya jangka waktu kontrak tersebut. Perhimpunan Ahli Pertambangan Indonesia (PERHAPI) menilai aturan dalam pasal 169b tersebut menimbulkan ketidakpastian dan berimplikasi negatif terhadap iklim investasi pertambangan di Indonesia. Sementara itu, sekretaris perusahaan Rio Tinto Indonesia, Budi Irianto mengatakan bahwa Rio Tinto Indonesia akan mengevaluasi rencana investasi mereka dan juru bicara PT Freeport Indonesia Mindo Pangaribuan mengatakan bahwa baik perusahaan maupun pemerintah Indonesia hendaknya konsisten menghormati kontrak yang sedang berlaku.

Kedua contoh kasus di atas menggambarkan meningkatnya ketidakpastian hukum di Era Pemerintahan Reformasi akibat penerapan peraturan yang retroactive. Hal ini memunculkan konflik antara Pemerintah dan investor, yang pada akhirnya berimplikasi negatif terhadap iklim investasi di Indonesia. Ketidakpastian hukum di Indonesia juga berakibat meningkatnya jumlah sengketa yang muncul antara investor asing dan Pemerintahan Reformasi atau antara investor asing dan Badan Usaha Milik Negara yang harus dibawa ke lembaga arbitrase internasional. Penyelesaian sengketa di lembaga arbitrase internasional ini sudah barang tentu memakan waktu dan biaya yang tidak terhitung banyaknya, sehingga dapat dikatakan menghamburkan uang rakyat.

Beberapa sengketa tersebut di antaranya melibatkan investor-investor besar, seperti: American Caithness Energy, L.L.C. dan Florida Power and Light Company (dalam kasus Karaha Bodas Company melawan Pertamina 
dan PT PLN di Tahun 2000); Mexican Cemex S.A. (dalam kasus Cemex Asia melawan Pemerintah Republik Indonesia di Tahun 2005); American Newmont (dalam kasus PT Newmont Nusa Tenggara melawan Pemerintah Republik Indonesia di Tahun 2009). Sebagian besar dari sengketa tersebut disebabkan tidak jelasnya aturan tentang prosedur divestasi di Indonesia, ditambah dengan tidak jelasnya pembagian kewenangan antara Pemerintah Pusat dan Pemerintah Daerah tentang siapa yang seharusnya bertanggung jawab atas proses divestasi penanaman modal asing di Indonesia. Pembangunan ekonomi di era Reformasi juga terhambat oleh sistem peradilan Indonesia yang sering mengingkari isi kontrak yang telah disepakati para pihak, tidak menghormati keputusan arbitrase dan tidak menerapkan aturan hukum sebagaimana mestinya. ${ }^{16}$ Pelaku usaha di dalam negeri maupun di luar negeri, yang beranggapan bahwa pengadilanpengadilan di Indonesia tidak memiliki kemampuan untuk menangani kasuskasus komersial atau perdagangan. Hal ini menyebabkan banyak keputusan pengadilan-pengadilan di Indonesia tidak konsisten, memihak dan tidak dapat diprediksi. Sistem hukum Indonesia yang buruk menempatkan Indonesia pada ranking ke-19 dari 24 negara di wilayah Asia Timur dan Pasifik, dalam hal kelancaran melakukan bisnis. ${ }^{17}$ Ranking Indonesia yang rendah ini membenarkan hasil survei yang sebelumnya dilakukan oleh Political and Economic Risk Consultancy (PERC) di tahun 2008, yang menempatkan Indonesia di ranking terbawah dari 13 negara-negara di Asia dalam hal sistem peradilannya. ${ }^{18}$

Walaupun Pemerintah Reformasi telah mendirikan Pengadilan Niaga sejak 1998 untuk menangani masalah-masalah hukum perniagaan, pengadilan ini belum dapat menjamin pemberian keputusan yang adil dan tidak memihak bagi investor asing. Keputusan-keputusan Pengadilan Niaga yang mengalahkan perusahaan-perusahaan asing di Indonesia telah menimbulkan kritik dan menguatkan pendapat umum tentang sistem peradilan Indonesia yang sewenang-wenang dan dipenuhi korupsi. Pada tahun 2002, Pengadilan Niaga memutuskan pailit PT Asuransi Jiwa Manulife Indonesia (AJMI), yang merupakan anak perusahaan dari perusahaan asuransi Kanada, Manulife Financial Corporation. PT AJMI yang didirikan pada tahun 1985 , merupakan perusahaan patungan yang $51 \%$

${ }^{16}$ Banyak "Izin Tambang Harus Diawasi, Freeport Indonesia Akan Patuhi Kontrak", [koran online] pada tgl 18 Desember 2008, diakses 26 December 2008) dari http://cetak.kompas.com/read/xml/2008/12/18/0045163/izin.tambang.harus.diawasi.

${ }^{17}$ Ranking Indonesia yang rendah ini membenarkan hasil survei yang sebelumnya dilakukan oleh Politial and Economic Risk Consultancy (PERC) di tahun 2008, yang menempatkan Indonesia di ranking terbawah dari 13 negara-negara di Asia dalam hlm. sistem peradilannya.

18 The World Bank Group Doing Business 2010 Report, June 2008 - May 2009, diakses pada tgl 28 Maret 2010 dari http://www.doingbusiness. org/economyrankings/. 
sahamnya dimiliki oleh Manulife Financial Corporation (Manulife), 40\% sahamnya dimiliki oleh perusahaan Indonesia, PT Dharmala Sakti Sejahtera (Dharmala), dan 9\% sahamnya dimiliki oleh International Finance Corporation (IFC), Juni tahun 2000 sewaktu Dharmala diputuskan bangkrut oleh Pengadilan Niaga. Kemudian saham Dharmala di AJMI dibeli semua oleh Manulife Kanada. Pengambilalihan saham Dharmala oleh Manulife ini dilakukan dengan persetujuan dari Pemerintah Indonesia dan IFC. AJMI menjadi salah satu dari tiga besar perusahaan asuransi di Indonesia yang pada tahun 2001 memperoleh keuntungan bersih sebesar Rp.75,5 miliar, dan memiliki aset seharga US\$ 360 juta. Akan tetapi, pada bulan Juni 2002, Dharmala menggugat pailit AJMI di Pengadilan Niaga dengan alasan AJMI telah gagal membayar deviden atau keuntungan perusahaan kepada Dharmala sejak tahun 1998 sampai dengan 2000 sebesar Rp.32,7 miliar. Dalam persidangan, AJMI berargumen bahwa mereka tidak membayarkan deviden karena terikat dengan keputusan Rapat Umum Pemegang Saham di pertengahan tahun 2000 yang memutuskan agar deviden tidak dibagikan karena situasi perekonomian Indonesia yang masih labil. Pengadilan Niaga tetap mengabulkan gugatan Dharmala dan memutus AJMI pailit dengan dasar telah terjadinya pelanggaran perjanjian joint-venture yang salah satunya menyepakati pembayaran deviden apabila AJMI memperoleh keuntungan. Atas keputusan Pengadilan Niaga tersebut, AJMI mengajukan kasasi ke Mahkamah Agung RI. Seminggu setelah dikeluarkannya keputusan Pengadilan Niaga, kurator yang ditunjuk Pengadilan Niaga memerintahkan AJMI untuk menghentikan bisnis mereka dan menutup 75 kantor cabang. Hal ini menyebabkan kepanikan pada pemegang polis asuransi AJMI. Keputusan Pengadilan Niaga ini semakin menguatkan kekuatiran para investor asing akan rendahnya kepastian hukum di Indonesia. Pemerintah Kanada mengajukan protes resmi kepada Pemerintah Indonesia atas keputusan Pengadilan Niaga tersebut. World Bank maupun International Monetary Fund juga menyatakan keprihatinannya terhadap penanganan kasus AJMI ini. Sementara IFC mulai mempertimbangkan kelangsungan investasinya di Indonesia. Mereka menguatirkan kenetralan Pengadilan Niaga dalam kasus ini dan mencurigai kemungkinan penyuapan terhadap majelis hakim untuk menjatuhkan perusahaan asing yang sehat dan menguntungkan. Ditengah-tengah tekanan masyarakat internasional, hanya satu bulan setelah dikeluarkannya keputusan Pengadilan Niaga tersebut, Mahkamah Agung RI mengabulkan permohonan kasasi AJMI dan membatalkan keputusan Pengadilan Niaga yang mempailitkan AJMI. Keputusan Mahkamah Agung ini di dasarkan pada alasan teknis, bukan alasan substantif, yaitu pemohon kepailitan, Dharmala, belum memperoleh izin hakim pengawas dan para kreditor AJMI yang lain untuk menggugat 
pailit AJMI, sebagaimana disyaratkan dalam Undang-Undang Kepailitan No. 4 Tahun $1998 .{ }^{19}$

Dua tahun setelah keputusan Pengadilan Niaga yang kontroversial di atas, pada bulan April 2004 Pengadilan Niaga kembali memutuskan pailit sebuah perusahaan asuransi yang sehat dan menguntungkan, yaitu PT Prudential Life Assurance. PT Prudential Life Assurance digugat pailit oleh seorang warga negara Malaysia, Lee Boon Siong, karena PT Prudential Life Assurance tidak membayarkan bonus keagenan kepada Lee Boon Siong sebesar Rp.1,43 miliar pada tahun 2003. Pengadilan Niaga mengabulkan gugatan kepailitan yang diajukan oleh Lee Boon Siong. Atas keputusan Pengadilan Niaga tersebut, Kedutaan Besar Kerajaan Inggris mengajukan protes, sedangkan Consultative Group on Indonesia (CGI), kelompok negara-negara dan lembaga internasional pemberi donor untuk Indonesia, menyoroti kasus ini dalam pertemuannya di Jakarta. PT Prudential Life Assurance mengajukan kasasi atas keputusan Pengadilan Niaga ke Mahkamah Agung RI. Pada bulan Juni 2004, Mahkamah Agung mengabulkan permohonan kasasi PT Prudential Life Assurance dan membatalkan keputusan Pengadilan Niaga. Mahkamah Agung berpendapat bahwa kasus Prudential melawan Lee Boon Siong bukan merupakan kasus kepailitan dan ketidakmampuan pembayaran hutang, tetapi kasus wanprestasi perjanjian keagenan yang seharusnya diputus oleh Pengadilan Negeri bukan Pengadilan Niaga. ${ }^{20}$

Belajar dari dua kasus kepailitan yang kontroversial ini, IMF meminta Pemerintah Reformasi untuk segera merevisi Undang-Undang Kepailitan yang telah disalahgunakan untuk mempailitkan dan melikuidasi perusahaanperusahaan asing yang sehat dan menguntungkan. Pada bulan September 2004, Dewan Perwakilan Rakyat menyetujui diundangkannya UndangUndang No. 37 Tahun 2004 tentang Kepailitan dan Penundaan Kewajiban Pembayaran Utang.

Berdasarkan Undang-Undang Kepailitan yang baru ini, kreditur tidak dapat lagi menggugat pailit perusahaan asuransi di muka Pengadilan Niaga. Hanya Menteri Keuangan yang dapat mengajukan gugatan kepailitan atas perusahaan asuransi. Ketidakpastian hukum di Indonesia juga mengakibatkan bank-bank di Indonesia enggan memberikan kredit yang

${ }^{19}$ David K. Linnan, "Insolvency Law and Institutions in Indonesia," in Insolvency Law in East Asia, ed. Tomasic Roman (England: Ashgate, 2006), hlm. 357-35.

${ }^{20}$ Pengadilan Pailitkan Prudential Life" [koran online] (23 April 2004, diakses 3 April 2010) dari http://www.tempo. co.id/hg/hukum/2004/04/23/brk,20040423-35,id.html. "MA Kabulkan Kasasi Prudential" [koran online] (8 Juni 2004, diakses 3 April 2010) dari http://tempo.co.id/ hg/ekbis/20 04/06/08/brk,20040608-07,id. html. "Prudential's Indonesian Directors Face Jail Threat Over Bankruptcy Charge" [koran online] (11 Mei 2004, diakses 3 April 2010) dari http://www.fi nancialexpress.com/ printe r/news/59761/. 
justru dibutuhkan oleh para pelaku usaha untuk menggerakan roda ekonomi. Undang-Undang No. 4 Tahun 1996 tentang Hak Tanggungan Atas Tanah Beserta Benda-Benda yang Berkaitan Dengan Tanah (Undang-Undang Hak Tanggungan) awalnya dimaksudkan untuk memberikan kepastian hukum bagi kreditur atau lembaga keuangan perbankan dan non-perbankan, serta debitur. Akan tetapi pada kenyataannya pelaksanaan Undang-Undang Hak Tanggungan ini dihadapkan pada banyak masalah. Eksekusi hak tanggungan tidak mudah untuk dilaksanakan, bahkan beberapa lembaga pemerintah menolak untuk melakukan eksekusi hak tanggungan. ${ }^{21}$

Hal ini disebabkan karena masih diberlakukannya yurisprudensi Mahkamah Agung dan beberapa fatwa Mahkamah Agung yang dibuat jauh sebelum diundangkannya Undang-Undang Hak Tanggungan ini dan isinya sudah tidak sesuai dengan undang-undang ini. Putusan Mahkamah Agung No. 3021/K/Pdt/1984, tanggal 30 Januari 1986, menyatakan bahwa lelang berdasarkan parate eksekusi (eksekusi langsung) tidak boleh dilakukan tanpa melalui fiat atau persetujuan Ketua Pengadilan Negeri. Sedang fatwa Mahkamah Agung tentang Grosse Akte No. 213/229/05/II/Um-Tu/Pdt tanggal 16 April 1985, No. 133/154/86/II/Um-Tu/Pdt tgl 18 Maret 1986, dan No. 147/168/86/II/Um-TU/Pdt tanggal 1 April 1986, mengharuskan bank melakukan prosedur gugatan lebih dulu di Pengadilan Negeri sebelum bank melakukan eksekusi agunan kredit macet. Yurisprudensi dan fatwa Mahkamah Agung yang masih diberlakukan walau bertentangan dengan isi dan tujuan Undang-Undang Hak Tanggungan ini jelas menimbulkan ketidakpastian hukum bagi kalangan perbankan. Larangan Mahkamah Agung bagi bank untuk melakukan eksekusi hak tanggungan secara langsung, karena bank harus melewati prosedur gugatan biasa, juga menyebabkan biaya tinggi bagi kalangan perbankan.

Ketidakpastian hukum dan biaya tinggi dalam proses eksekusi penggunaan kredit macet, menjadi salah satu penyebab keengganan bankbank di Indonesia untuk menyalurkan kredit bagi pelaku usaha di Indonesia. Hal ini berakibat pada penurunan jumlah kredit yang disalurkan perbankan Indonesia kepada perusahaan-perusahaan manufaktur. Pada tahun 1985, hampir $40 \%$ kredit bank disalurkan ke industri manufaktur. Pada November 2009, industri manufaktur hanya memperoleh 17,2 persen dari kredit bank yang ada. Saat ini, mayoritas kredit bank disalurkan ke segmen pembiayaan konsumsi dan pembangunan properti. Kalangan perbankan menganggap sektor konsumsi dan properti kurang berisiko dan jangka pengembalian investasinya lebih cepat dibandingkan dengan industri manufaktur yang berisiko tinggi dengan jangka pengembalian investasi yang lama.

\footnotetext{
${ }^{21}$ St Laksanto Utomo, Menyoal Eksekutorial Hak Tanggungan [artikel online] (Antara News, 1 Januari 2009, diakses 3 April 2010) dari http://www.antara.co.id/ print/ 1230784015.
} 


\section{Efisiensi dalam Sistem Hukum}

Analisis ekonomi terhadap hukum (The Economic Analysis of Law) ini dimaksudkan sebagai sebuah pendekatan ekonomi terhadap hukum atau dengan kata lain studi kritis terhadap hukum melalui pendekatan ekonomi (Critical Legal Studies with the antecedents of economic approach), yang umumnya dikenal sebagai "Economic Analysis of Law" muncul pertama kali melalui pemikiran utilitarianisme Jeremy Bentham (1789), yang menguji secara sistemik bagaimana orang bertindak berhadapan dengan insentifinsentif hukum dan mengevaluasi hasil-hasilnya menurut ukuran-ukuran kesejahteraan sosial (social welfare). Pemikiran utilitarianisme hukum Bentham tersebut tersebar dalam tulisan-tulisannya berupa analisis atas hukum pidana dan penegakannya, analisis mengenai hak milik (hukum kepemilikan), dan 'substantial treatment' atas proses-proses hukum. Namun, pemikiran ala Bentham tersebut terhenti sampai tahun 1960-an, dan baru kemudian setelah, Richard Posner (1972), dengan bukunya yang berjudul "Economic Analysis of Law" dan penerbitan "Journal of Legal Studies". Yaitu adalah suatu pendekatan teori hukum yang menggunakan metode ekonomi dan hukum. Ini termasuk penggunaan konsep-konsep ekonomi untuk menjelaskan efek hukum, untuk menilai mana aturan-aturan hukum ekonomi yang efisien. Begitu banyaknya perdebatan tentang hukum yang terjadi dalam periode masa peningkatan efisiensi ekonomi. Sebuah sekolah hukum di Chicago menganggap teori ini memiliki aspek normatif, sehingga terdapat penggunaan analisis ekonomi sebagai mediator dalam mengevaluasi peraturan-peraturan baru, khususnya dalam pembuatan undang-undang, tetapi sekolah hukum inipun melontarkan opini bahwa tidak sesederhana itu dalam mengevaluasi pembuatan undang-undang hanya dengan pendekatan ekonomi semata, akan tetapi melalui seluruh proses yang menyangkut pembuatan undang-undang yang berdasarkan asumsi: "pembuat undangundang adalah orang yang benar-benar maksimal menggunakan rasionya".

Sebuah perundang-undangan sangat memerlukan penafsiranpenafsiran bahkan bila perlu menggunakan pengadilan/hakim untuk menafsirkannya. Menurut Posner, pengadilan mempunyai dwifungsi; pertama, menafsirkan perjanjian-perjanjian kelompok yang berkepentingan. Mengapa kelompok tersebut bisa-bisanya membubuhi draft perundangundangan; dan kedua, menyediakan pelayanan bagi masyarakat awam dalam memecahkan masalah yang diperdebatkan. Salah satu pentingnya pengadilan tidak hanya memberlakukan peraturan perundang-undangan akan tetapi menginterpretasikan undang-undang tersebut sehingga dapat membantu dalam meningkatkan efisiensi ekonomi.

Pengadilan Perikanan adalah Pengadilan Khusus di lingkungan peradilan umum yang berwenang memeriksa, mengadili, dan memutus tindak pidana di bidang perikanan. Undang-Undang Nomor 31 Tahun 2004 
tentang Perikanan yang diundangkan pada tanggal 6 Oktober 2004 merupakan salah satu tonggak perubahan yang mendasar dari suatu proses penegakan hukum di bidang perikanan melalui Pengadilan Perikanan di Indonesia yang untuk pertama kali dibentuk di Pengadilan Negeri Jakarta Utara, Medan, Pontianak, Bitung, dan Tual. Dalam Pasal 71 ayat (2) dalam undang-undang ini diatur tentang Pengadilan Perikanan yang merupakan pengadilan khusus yang berwenang memeriksa, mengadili, dan memutus tindak pidana di bidang perikanan yang berada pada lingkungan Peradilan Umum. Penegakan hukum terhadap tindak pidana di bidang perikanan yang terjadi pada saat itu sebelum undang-undang ini ada mengalami berbagai hambatan. Untuk itu diperlukan metode penegakan hukum yang bersifat spesifik yang menyangkut hukum materil dan hukum formil pada Pengadilan Perikanan.

Sebagai lembaga pengadilan, Pengadilan berkewajiban menjawab langsung problematika yang diajukan masyarakat, yaitu harus dijawab segera, lugas, tegas, dan tidak boleh diambangkan dalam satu bentuk putusan pengadilan. Putusannya pun bisa diterima secara nalar di kalangan institusi kehakiman, forum ilmu pengetahuan hukum, masyarakat luas, dan para pihak yang berperkara. Putusannya perlu kecermatan sehingga tidak berpotensi untuk dikoreksi atau dibatalkan oleh jenjang pengadilan berikutnya. Putusannya perlu mencermati agar sejalan dengan doktrin ilmu pengetahuan hukum. Pada gilirannya, putusan itupun wajib memperhatikan tanggapan masyarakat luas, dan dalam lingkup yang spesifik juga tanggapan dari mereka yang terlibat langsung di dalam perkara itu.

Contoh analisis ekonomi atas hukum dalam perundang-undangan di Indonesia, yang di dasarkan atas prinsip efisiensi ekonomi (economic efficiency). Pemilihan prinsip efisiensi ini berdasarkan pada kemudahannya untuk dipahami, karena tidak memerlukan rumusan-rumusan teknis ilmu ekonomi atau rumus berupa angka-angka. Yang menjadi fokus perhatian adalah berkenaan dengan kemungkinan munculnya ketidakefisienan (inefficiency) dari pembentukan, penerapan, maupun penegakan hukum (enforcement) dari peraturan perundang-undangan, yaitu terhadap tindak pidana bidang perikanan, yang mencakup penyidikan, penuntutan, dan pemeriksaan di sidang pengadilan terhadap limpahan perkara pidana perikanan yang diajukan oleh kejaksaan ke pengadilan tentang adanya tindak pidana bidang perikanan kapal ikan asing yang melakukan illegal fishing dengan locus di Zona Ekonomi Eksklusif Indonesia (ZEEI) dapat terselesaikan proses pengadilan memenuhi prinsip efisiensi yaitu cepat, cermat, dan berbiaya ringan, sebagaimana diamatkan Undang-Undang Nomor 45 tahun 2009 tentang perubahan atas Undang-undang Nomor 30 tahun 2004 tentang Perikanan yaitu dengan memperhatikan tanggal masuk 
perkara dan tanggal putusan dimana menurut Pasal 80 ayat (1), berbunyi sebagai berikut:

"Dalam jangka waktu paling lama 30 (tiga puluh) hari terhitung sejak tanggal penerimaan pelimpahan perkara dari penuntut umum, hakim harus sudah menjatuhkan putusan".

Dengan locus ZEEI sebagai tempat kejadian perkara (TKP) tindak pidana bidang perikanan yang telah diselesaikan menunjukkan terselenggaranya kegiatan-kegiatan dari kedaulatan sekaligus merupakan pengejawantahan daripada kedaulatan itu sendiri. Berdasarkan konsepsi Zona Ekonomi Eksklusif UNCLOS 1982 melalui Undang-Undang Nomor 17 Tahun 1985 dan Pasal 2 Undang-Undang Nomor 5 Tahun 1983 tentang Zona Ekonomi Eksklusif Indonesia di ZEEI terdapat dua rezim hukum di perairan di atas landas kontinen 200 mil, yaitu perairan Zona Ekonomi Eksklusif 200 mil dari garis pangkal laut teritorial dan perairan di atas landas kontinen di luar 200 mil sebagai laut lepas. Disimpulkan bahwa perairan di atas landas kontinen 200 mil yang berhimpit dengan Zona Ekonomi Eksklusif adalah perairan zona ekonomi eksklusif. Di dalam perairannya, dasar laut dan tanah di bawahnya yang meliputi kekayaan hayati dan nonhayati dan juga mineral. Sedangkan perairannya tetap merupakan laut lepas yang dapat dilalui oleh kapal-kapal dari semua negara.

Di perairan di atas landas kontinen di luar 200 mil sesuai dengan statusnya sebagai laut lepas, maka pengaturannya tunduk pada rezim hukum laut lepas yang dapat dinikmati oleh semua. Di perairan ini negara pantai memunyai hak berdaulat untuk tujuan eksplorasi dan eksploitasi terhadap kekayaan negara-negara baik terhadap pelayarannya maupun sumber-sumber kekayaan alam hayati maupun non-hayati termasuk sumber mineral di perairan tersebut. Bagaimana dengan kerugian negara akibat illegal fishing oleh kapal ikan asing yang lokusnya adalah di ZEEI-WPP-RI (Wilayah Pengelolaan Perikanan Republik Indonesia) 711 yang wilayahnya meliputi Perairan Selat Karimata, Laut Natuna, dan Laut Cina Selatan.

\section{Penutup}

Pengadilan Perikanan adalah Pengadilan Khusus di lingkungan peradilan umum yang berwenang memeriksa, mengadili, dan memutus tindak pidana di bidang perikanan. Undang-Undang Perikanan merupakan salah satu tonggak perubahan yang mendasar dari suatu proses penegakan hukum di bidang perikanan melalui Pengadilan Perikanan dengan menerapkan prinsip efisiensi.

Pemilihan prinsip efisiensi ini berdasarkan pada kemudahannya untuk dipahami, karena tidak memerlukan rumusan-rumusan teknis ilmu ekonomi atau rumus berupa angka-angka. Yang menjadi fokus perhatian adalah berkenaan dengan kemungkinan munculnya ketidakefisienan (inefficiency) 
dari pembentukan, penerapan maupun penegakan hukum (enforcement) dari peraturan perundang-undangan, yaitu terhadap tindak pidana bidang perikanan, yang mencakup penyidikan, penuntutan, dan pemeriksaan di sidang pengadilan terhadap limpahan perkara pidana perikanan yang diajukan oleh kejaksaan ke pengadilan tentang adanya tindak pidana bidang perikanan kapal ikan asing yang melakukan illegal fishing dengan locus di Zona Ekonomi Eksklusif Indonesia (ZEEI) dapat terselesaikan proses pengadilan memenuhi prinsip efisiensi yaitu cepat, cermat, dan berbiaya ringan.

\section{Daftar Pustaka}

\section{A. Buku}

Amsden, 1992. Industry in Poland Stuctural Adjustment Issues and Policy Option, Paris : OECD : Centre for Co-operation with the European Economic in Transsition, Washington DC; OECD Publisher and Information Centre.

Bakarbessy, Leonora, Klausula Pilihan Hukum ( Choice of Law ) dan Pilihan Hukum ( Choice of Forum ) dalam Transaksi Bisnis Internasional, Yuridika, Vol, 14 No,1, Januari-Pebruari 1999.

Bureau of Industry Economic, Foreign Direct Invesment in APEC: A Survey of the Issues, Report 95/21, Canbera: Australian Governement Publishing Service, November 1995.

Cillis, Malcolm, et, al., Economic of Development, $4^{\text {th }}$, New York : W,W Norton, 1996, dalam : Theodore H, Moran, Foreign Direct Invesment and Development : The New Policy Agenda for Developing Countries and Economic in Transition, Institute For International Economic, Washington DC, Desember 1998.

Grabowski, 1996. Development Economic, Cambridge Mass, Blackwell Business, USA.

Grant, Alastair B., 1996. General Summary of the Coal Development, disusun dalam Mining in Indonesia: Fifty Years Development, 1945 1995, Indonesian Mining Association, editor: Marangin Simatupang, Soetaryo Sigit, Beni N, Wahju.

HS, Salim, 2010. Hukum Pertambangan Indonesia, Cetakan Kelima, Jakarta: Penerbit Raja Grafindo Persada.

J, Atkinson, 1995. APEC-Winner and Losers, Dossier 34, Canberra: Australian Council for Overseas Aid.

Juwana, Hikmahanto, Kepastian Hukum di Sektor Pertambangan Pasca Disahkannya UU Minerba, (Makalah disampaikan pada Seminar 
Hukum Online, UU Minerba: Nasionalisasi atau Privatisasi), Jakarta, Garuda Hotel Niko, 21 Januari 2009.

Krueger, 1990. Government Failures In Development, Journal of Economic Pers-pective 493.

Linnan, David K., 2006. Insolvency Law and Institutions in Indonesia, in Insolvency Law in East Asia, ed, Tomasic Roman England: Ashgate.

Mangkusubroto, Kuntoro, 1996. Mikneral Development and Investment Policy in Indonesia, disusun dalam Mining in Indonesia: Fifty Years development, 1945-1995, Indonesian Mining Association, editor: Marangin, Soetaryo Sigit, Beni N, Wahyu.

Mertokusumo, Sudikno, 2002. Mengenal Hukum, Yogyakarta: Liberty.

OECD. Economic Assessment of Indonesia 2008 (OECD, 2008) Asian Development Bank.

Roth, A., 1949. The Minimum Standard of International Law Applied to Aliens.

Rueschemeyer, and Evans, 1992. The State and economic Transformation Toward and Analysis of the Conditions Underlying Effective Interventing dalam L. Putterman and D. RUeschemyer (eds) State and Market in Development, Lynne Riener Publisher, Boulder.

Saleng, Abrar, 2004. Hukum Pertambangan, Yogyakarta: UII Press.

Sigit, Sutaryo, 1996. Mining in Indonesia 1945-1995, disusun dalam Mining in Indonesia: Fifty Years development, 1945-1995, Indonesian Mining Association, editor: Marangin, Soetaryo Sigit, Beni N, Wahyu.

Smith, D,N., 1992. Foreign Invesment in National Resources : What Can Go Wrong, 29 dalam HP Kee et, Al, (eds) Current Developments in International Invesment Law, Butterworth.

Sutedi, Adrian, 2011. Hukum Pertambangan, Cetakan Pertama, Jakarta: Sinar Grafika.

Trebilcock, Michael J., "Law and Economics" The Dalhousie La Journal, vol, 16, no, 2 (Fall 1993) dalam A,M, Tri Anggraini, 2003, Larangan Praktek Monopoli dan Persaingan Tidak Sehat : Perse Illegal atau Rule of Reason, Jakarta: Fakultas Hukum Universitas Indonesia.

Weber, Max, Die Protestantische Ethik und der 'Geist' des Kapitalismus (1905) diterjemahkan oleh Talcott Parsons, The Protestant Ethic and the Spirit of Capitalism (New York: Dover Publications, 2003) David M, Trubek, "Max Weber on Law and the Rise of Capitalism", Wisconsin Law Review 3 (1972).

Usman, Syaikhu., 2001, et, al., Regional Autonomy and the Business Climate: Three Kabupaten Case Studies from North Sumatra Indonesia: SMERU.

$\mathrm{R}$, Vernon., International Invesment and International Trade in Product Cycle; 2 Quarterly Journal of Economics, 1966, Vol, 80. 
World Bank, 1997. Global Development Finance, Washington.

\section{B. Peraturan Perundang-undangan}

Undang-undang tentang Penanaman Modal. UU No. 25, LN No. 67 Tahun 2007, TLN No. 4724,

Undang-undang tentang Penanaman Modal Asing. UU No. 1, LN No. 125 Tahun 1967, TLN No. 4437,

Undang-Undang tentang Ketentuan-Ketentuan Pokok Pertambangan, Undang-Undang No. 11 Tahun 1967 LNth. 1967 No. 22 TLN. No. 4959.

Undang-Undang tentang Pertambangan Mineral dan Batubara, UndangUndang No. 4 Tahun 2009 LN th. 2009 No. 22 TLN. No. 4959.

Undang-undang tentang Pemerintah Daerah. UU No. 32, LN No. 125 Tahun 2004, TLN No. 4437

Peraturan Pemerintah Republik Indonesia No. 32 Tahun 1969 tentang Pelaksanaan UU No. 11 Tahun 1967 tentang Ketentuan Pokok-Pokok Pertambangan, LN th. 1969 No.60 TLN. No.2916

Peraturan Pemerintah Republik Indonesia No. 22 Tahun 2010 tentang Wilayah Pertambangan, LN th. 2010 No.28 TLN. No.5110

Keputusan Presiden Republik Indonesia No. 29 Tahun 2004 tentang Penyelenggaraan Penanaman Modal Asing dan Penanaman Modal Dalam Negeri Melalui Sistem Pelayanan Satu Atap, tanggal 12 april 2004

Keputusan Presiden Republik Indonesia, tentang Ketentuan Pokok Perjanjian Karya Pengusahaan Pertambangan, Batubara, Nomor 75 Tahun 1996, tanggal 25 September 1996

\section{Internet}

Richard A. 2007. Posner, Economic, Analysis of Law, $7^{\text {th }}$ ed. Wolters Kluwer Law \& Business. David D. Friedman, Law and Economics [artikel online] diakses 27 dari http://www.econlib.org/library/Enc1/LawandEconomics.html

Romli Atmasasmita, pada Seminar Nasional "Peran Hakim dalam meningkatkan Profesionalisme Hakim Menuju Peradilan Yang Agung", diselenggarakan IKAHI dalam rangka Ulang Tahun IKAHI ke 59 Tanggal 25 April 2012

St Laksanto Utomo, Menyoal Eksekutorial Hak Tanggungan [artikel online] (Antara News, 1 Januari 2009, diakses 3 April 2010) dari http://www.antara.co.id/print/1230784015

\section{Lain-lain}


Charles Himawan, "Hukum Macet Penyebab Utama Kredit Macet" KOMPAS, 5 dan 6 Agustus 1993,

Clifford Chance \& Mochtar Karuwin Komar, New opportunities for coal mining investment in Indonesia, Client Briefing, September 2009. 